Отримано: 10 січня 2018 р.

Прорецеензовано: 17 січня 2018 р.

Прийнято до друку: 22 січня 2018 р.

e-mail: cerkas@ukr.net
Атаманенко В. Інвентар Степанської волості 1614 року як історичне джерело / В. Атаманенко // Наукові записки Національного університету «Острозька академія». Серія «Історичні науки». - Острог, 2018. - Вип. 27 : На пошану Володимира Трофимовича. - С. 180-186.

DOI: $10.25264 / 2409-6806-2018-27-180-186$

УДК 930.2:94(477).03«16»

\title{
Віктор Атаманенко
}

\section{ІНВЕНТАР СТЕПАНСЬКОЇ ВОЛОСТІ 1614 РОКУ ЯК ІСТОРИЧНЕ ДЖЕРЕЛО}

У статті характеризується інвентар Степанської волості князя Януша Острозького 1614 р. як історичне джерело. Основна увага приділясться інформаційному потенціалу иъого документа в ряді сочіально-економічних аспектів історії Волині, в першу чергу - під кутом вивчення урбанізаиіі Волинського Полісся. Вивчення иього значного за розміром документу дає можливість дослідження структури міських та сільських поселень, фільваркових дворів, особливостей організаиії господарства у замкових та посесорських маєтках.

Ключові слова: джерела описово-статистичного характеру; інвентарі; латифундї; урбанізаційні прочеси; фільваркове господарство.

\section{Виктор Атаманенко}

\section{ИНВЕНТАРЬ СТЕПАНСЬКОЙ ВОЛОСТИ 1614 Р. КАК ИСТОРИЧЕСКИЙ ИСТОЧНИК}

В статье характеризуется инвентарь Степанской волости князя Януша Острожского 16142. как исторический источник. Основное внимание приделается информачионному потенциалу этого документа в изучении ряда сочиально-экономических аспектов истории Волыни, в первую очередь - с точки зрения изучения урбанизации Вольнского Полесья. Изучение этого значительного по размеру документа дает возможность исследования структуры городских и сельских поселений, фольварковых дворов, особенностей организации хозяйства в замковых та посессорских имениях.

Ключевые слова: источники описательно-статистического характера; инвентари; латифундии; урбанизационные процессы; фольварочное хозяйство.

\section{Viktor Atamanenko}

\section{THE INVENTORY OF THE STEPAN VOLOST OF 1614 AS A HISTORICAL SOURCE}

The article describes the inventory of the Stepan volost of Prince Janusz Ostrozky in 1614 as a historical source. The main attention is paid to the informative potential of this document in a number of socio-economic aspects of the history of Volyn, first of all - from an angle of research of the urbanization of Volynian Polissya. The study of this large-scale document gives an opportunity to study the structure of urban and rural settlements, Folwark estates, peculiarities of the economic organization in the castles and possessory estates.

Keywords: descriptive-statistical sources; inventory; latifundia; urbanization processes; folwark estate.

Джерела вивчення історії волинських латифундій другої половини XVI - першої половини XVII ст. у територіальному, хронологічному та видовому вимірах представлені вкрай нерівномірно. Значною мірою це стосується і такого їх різновиду, який найповніше характеризує латифундії як господарські структури, що найчастіше й визначало магнатський статус тієї чи іншої особи та роду. Ця група джерел представлена в структурі джерельної бази різноманітними категоріями джерел описово-статистичного характеру, але для різних родин та різних регіонів Волині стан їх збереженості помітно відрізняється. Серед таких документів вирішальне значення для дослідження проблем соціально-економічної історії має група документів, створюваних безпосередньо у сфері діяльності господарських та фіскальних структур, як державних, так і приватних. Для досліджуваного періоду можна говорити про переважання в структурі джерел описово-статистичного характеру документів 
загальнодержавного фіскального обліку для другої половини XVI ст. Натомість, документи господарсько-правового обліку, які мали внутрішньодоменіальне походження, для цього часу характеризуються нерегулярністю створення - йдеться про такі групи джерел статистичного характеру, як інвентарі. Саме вони й складають основу джерельної бази для XVII ст.

Степанщина стала об’єктом вивчення сучасних істориків у цілому ряді напрямків. Це і володільча історія, і окремі сторони вивчення монастирів, й окремі аспекти соціальної та господарської проблематики. Чи не найзначніші праці стосуються історії населених пунктів. При цьому, до наукового обігу вводилися й публікації (в тому числі й передруки) джерел, які стосуються Степанської волості $[1 ; 2 ; 3 ; 4 ; 5 ; 8 ; 9 ; 109 ; 14]$.

В українській історіографії найчастіше використовують підсумкові, а іноді - й первинні, поборові реєстри. Сумарні податкові реєстри по Волинському воєводству збереглися за 1570, 1577, 1583 , тариф подимного 1629 рр. (опубліковані) та за 1576, 1582, 1589 рр. (неопубліковані) [7; 11; 15]. В них достатньо рівномірно представлена вся територія Волинського воєводства, за винятком тих поселень, які звільнялися від сплати податків через знищення чи спустошення. 3 інших державних облікових документів, використовуваних істориками, необхідно відзначити описи державних володінь Волині - Володимирського, Луцького, Кременецького та Ковельського ключів/староств. 3 них тільки два останні були значними за розмірами, а Ковельське староство містило в своєму складі три міста. Таким чином, описи Ковельського староства другої половини XVI - першої половини XVII ст. можуть служити підставою для вивчення явищ соціально-економічного життя Волинського Полісся і забезпечене воно джерельною базою достатньо репрезентативною тематично та хронологічно, а також і різноманітною за категоріями та соціальними функціями. В той же час, такі регулярні “статистичні обстеження” охоплювали лише незначну частину маєтностей Волинського воєводства, а для поліської частини якого дані стосовно Ковельщини є унікальними, особливо зважаючи на їх стан збереженості.

Подібної кількості джерел описово-статистичного характеру внутрішньодоменіального походження не збереглося для жодної поліської приватновласницької латифундії, в тому числі, й для Степанської волості. Для останньої, правда, зберігся інвентар, створений у 1614 р. Він описує міста, сільські поселення, фільваркові комплекси, податки та розміри прибутків. Інвентар відобразив також структуру Степанської волості. Але найдавніші кількісні показники знайшли відображення у поборових документах - реєстрі 1577 р.. який відображає стан міста та волості на час їх переходу до рук кн. В.-К. Острозького. На цей час у складі волості знаходилося одне місто та 39 сіл, 3 яких 12 були посесорськими - знаходилися в держанні слуг-клієнтів.

Подимний реєстр 1629 р. дає можливість порівняння характеристик поліських латифундій. На їх основі видно, що на цей час найбільшими на Поліссі за кількістю населення та числом поселень були волості Степанська, Чорторийська та Ковельське староство. Вони відзначалися й вищим рівнем урбанізації. 3-поміж них виділяється перша - за всіма поданими в реєстрі параметрами (крім кількості міських поселень) вона охоплює від 22 до 26 відсотків сумарних даних. Таким чином, показники по Степанській волості можна вважати достатньо репрезентативними для вивчення поліських латифундій східної Волині [6, с. 37].

Практично всі збережені документи описово-статистичного характеру відносяться до часів володіння Степанню кн. Острозькими. Місто з волостю відійшло до кн. К.І. Острозького в результаті його першого шлюбу - з кн. Тетяною Гольшанською на початку XVII ст.; претензії на Степань, правда, висували родичі кн. С. Гольшанського, але маєток, хоча в окремі періоди не повністю, залишився в руках Острозьких [14]. На 70-ті роки XVI ст. Степань була досить значним, але єдиним на території значної за розмірами латифундії, міським поселенням, в якому знаходилося 246 будинків. Про розвиток торгівлі може свідчити кількість ринкових будинків - 30, а також відсутність у їх власників у користуванні землі. В той же час, поборовий реєстр фіксує незначне число торговців-перекупнів - 10. Але торгівлею займалися не тільки вони, але й ринкові та вуличні мешканці, а також ремісники. Останніх в Степані було 25. У селах волості тільки у Кричильську (Кричельську) проживало 2 ремісники. Це могло свідчити про тенденцію його перетворення на міське поселення, але ця спроба виявилася невдалою $[12$, с. 60,69$]$. В обох випадках ремісники не мали в своєму користуванні землі. Досить значною була роль землеробства у заняттях степанських міщан. По півдворища мали 56 власників вуличних будинків, по «трохи ріллі» - 23 городники, городи - 10 перекупнів, 50 мешканців «убогих домів» та 41 мешканець вуличних будинків. Не мали в користуванні земельних діля- 
нок, але, можливо, були задіяні у сільськогосподарських заняттях 20 підсусідків, оскільки вони володіли худобою [14. s.39 - 40]. Села волості були невеликими за розмірами, що не могло не впливати і на розвиток міста та створення нових міських поселень [15. s. 39 - 40]. Так, за поборовим реєстром 1589 р. у Степанській волості названо 30 сільських поселень, найбільшими з яких були Городець, Любаша, Кричельськ, Жалин, Золотолин. Чисельність мешканців Степані практично не змінилася - кількість міських будинків дорівнювала 242, не рахуючи трьох рудницьких товаришів. Ринкових будинків залишилося 30, але збільшилася кількість вуличних (з 91 до 114) та перекупників (з 10 до 15) та зменшилася кількість убогих будинків (з 50 до 35). Не змінилася чисельність ремісників (25), а замість городників (23) та підсусідків (20) реєстр 1589 р. згадує тільки 19 коморників. Вся міська земля подана сумарно як 72 одиниці «міської ріллі», яка відповідно до норми оподаткування становила півдворища чи півволоки, та 35 городів, які перебували у користуванні власників убогих халуп. Очевидно, землею володіли і чотири степанські священики [11, s. 15 - 17]. Скоріше за все, розмір землі, яка перебувала у користуванні міщан, трохи зріс. В обох реєстрах відсутні згадки поселень, які згодом одержали міський статус. Можливо, як сільські поселення Деражня та Бережниця виникли згодом або одразу засновувалися як міста, на «сирому корені».

Загалом, як свідчать дані поборових реєстрів, за власне міськими показниками - розміри Ринку, кількість будинків, чисельність ремісників та перекупників - Степань можна віднести до розвинутих приватновласницьких міст Волині. На 1589 рік за кількістю ринкових будинків Степань поступалася тільки Костянтинову та Острополю (засновані кн. В.-К. Острозьким у слабко урбанізованій південно-східній Волині саме як торгівельні осередки); за кількістю будинків вуличних - ім же, а також Острогу, Олиці, Корцю, Ковелю, Торчину та Колкам; за кількістю перекупнів - Олиці, Ковелю, Острогу [6, с. 38]. Показником розвитку міста була й чисельність у ньому церков, яка також належала до найвищих показників по приватновласницьких містах Волині.

Хронологічно останні свідчення описово-статистичних джерел стосовно Степані та волості відносяться до 1629 р. Вони відображені також у реєстрі державного оподаткування. На цей час до складу волості входило 59 поселень. У ньому знаходилося три міста - Степань, Бережниця та Деражня, а 23 села були посесорськими. Міське населення складало майже $35 \%$ всього населення (димів-помешкань). Найбільшим був центр волості, який значно збільшився за розмірами і в якому нараховувалося 636 будинків (з яких 78 погоріли під час пожежі 1627 р.). Степані помітно поступалися Бережниця (423 дими) та Деражня (351 дим). Більшу кількість міських димів мали тільки Острозька та Корецька волості; за загальною кількістю димів Степанська волость поступалася тільки останній. Найбільшими сільським поселеннями з кількістю димів понад сто були Городець, Кричельськ, Постойне, Рокитна [7, с. 33 - 34].

Отже, свідчення податкових документів фіксують для Степанської волості крайні збережені, початкову та кінцеву, часові точки наявності узагальнюючих кількісних показників. Особливістю податкової документації, окрім іншого, є фіксація населення у податкових категоріях, що часто не дає можливості здійснювати соціально-економічний аналіз. Це найбільш яскраво помітно на прикладі подимного реєстру 1629 р., коли на основі уніфікації всі оподатковувані одиниці було зведено до диму. Подолати даний недолік значною мірою дають приватновласницькі (внутрішньодоменіальні) документи, в тому числі й інвентарні описи. Таким є інвентар 1614 р., який було створено у жовтні при подачі волості в управління Адамові Золотолинському.

Міський комплекс Степані традиційно складався з замку з житловими та господарським будівлями, власне міста та Луцького та Дубровицького передмість. Окрім того, при місті знаходилися фільварок, на який працювали селяни Великого та Малого Медськів і Любаші, та звіринець. Замковими були винесені з замку за Луцьку браму стайня та сад, в якому росли кількадесят фруктових дерев та виноград (drzewa rodzianego kilkadziesiat, wino iest). Очевидно, під замковим контролем знходилася й пристань. Як така, вона в тексті інвентаря не виділяється, але він фіксує річкові судна (ком'яги) на p. Горинь (коmiag x(iążęcia) iego mczy na rzecze Horiniey). Їх на час створення документа було 16, а зі збудованих у 1614 р. по два було відправлено до Острога та Дубна і три продано [13, арк. 111 112зв., 117, 119, 119зв., 120 - 121зв.]

Основною та найпрестижнішою міською дільницею був Ринок. Для Степані в інвентарі 1614 p. він виділяється не за назвою, яка в тексті, можливо, випадково була пропущена, а структурно, передуючи опису вулиць. На ньому знаходилося 42 будинки. В ринкових будинках, крім міщан, мешкали (чи мали будинки) степанський староста, бурграбій, микільський та спаський священики, паламар, 
війт, лісничий, мостовничий, возний, орендар, замкові писар, гончар, золотар, воротний та костельний мельник. Окрім старостинського, на Ринку було ще три шляхетські будинки. Чотирма будинками володіли представники єврейської громади міста [13, арк. 113].

На чи біля ринкової площі, очевидно, знаходився костел. Його описання було подано в кінці опису міста, навіть після сумаріуша прибутків. При цьому були зазначені цвинтар, плебанія та школа. Останні дві вміщено і серед ринкових будинків [13, Арк. 113, 118 зв.]. Крім школи при католицькому костелі в місті знаходилася єврейська школа (малася на увазі синагога, при якій існувала і школа). Згадується також православний («руський») шпиталь, при якому чи при якійсь із православних церков також міг існувати освітній заклад [13, арк. 113 зв., 116].Згадуючи священиків, інвентар не зазначає розташування церков.

Вулична мережа Степані складалася з шести вулиць - Риболовської, від Дубровицької брами до Ринку, від Радька, під парканом, від Харка Скупки, від Васька Кир'яховича. Найбільшою, бо на ній знаходилася майже третина всіх оподатковуваних міських будинків, була вулиця Риболовська (151 будинок на різних ділянках). Найменшою була вулиця під парканом - на ній знаходилося 25 будинків. Неміщанські будинки знаходилися на вулицях Риболовській та від Дубровицької брами до Ринку. Священики мали будинки на вулицях Риболовській (пречистенський, степановський, диякон), від Радька (спаський) [13, арк. 113 - 117]. Як це відображено і в поборовому реєстрі 1589 р., в Степані на 1614 р. проживало чотири священики. Можливо, стільки ж було і церков - Миколаївська, Спаська, Пречистенська; невідомо, чи згаданий в інвентарі отець степанівський мав прихід у місті чи в якихось селах.

Інвентарні описи дають можливість визначити, приблизно звичайно, національну структуру населення. Так, стосовно Степані можна говорити про звичну для волинських міст наявність єврейської громади. Вона не була значною і включала до свого складу $24-28$ родини (близько $4-5 \%$ будинків). Чотири єврейські будинки знаходилися на ринковій площі. Решта єврейських родин приблизно порівно замешкували вулиці від Дубровицької брами до Ринку (7 - 10 будинків) та вулиці від Харка Скупки (13 - 14 будинків). Інтервальність даних в обох випадках пов'язана 3 ймовірним віднесенням деяких мешканців до єврейської громади м. Степань. Польська, чи, скоріше, католицька, громада була в Степані незначною. Невідомою є конфесійна належність шляхти, яка мала помешкання в місті - iї більшість (якщо не всі) належали до місцевої знаті, давніх слуг кн. Острозьких, включно зі введеним у посаду степанського старости А. Золотолинським. Так чи інакше, завданням поширення католицизму мав служити тільки-но заснований кн. Я. Острозьким степанський костел (варто відзначити існування костелів і у інших містах волості [13, арк. 134, 150 зв.]). 3-поміж шляхти ймовірними членами польської громади чи прихожанами костелу могли вважатися Ян Лях (вул. Риболовська), Сжи Городничий (вул. від Дубровицької брами до Ринку) та Венцлавиха (Дубровицьке передмістя) - явно замало для повноцінно функціонуючої католицької святині. Таким чином, можна говорити про те, що степанський костел зі школою ставив (точніше, перед ним ставилося) завдання проповіді католицизму. Певною мірою це підтверджується даними сумаріушу листів кн. Острозьких до степанського Свято-Михайлівського монастиря, який міститься у його інвентарі 1627 р. [1; 2; 9]. Троє степанчан носили прізвисько «Москаль», але чи це були росіяни точно сказати неможливо.

Степанські передмістя - Луцьке та Дубровицьке - були невеликими. На першому знаходилося 9 , а на другому - 55 будинків, а також 3 пустки [13, арк. 117]. Луцьке передмістя повинно було бути знищене за наказом кн. Януша Острозького. На ньому чи біля нього, очевидно, проживали рибалки, свідчення про яких в тексті знаходиться між описаннями передмість. Їх імена в інвентарі не було наведено, навіть точного числа їх укладачі вказати не могли - менше чи більше десяти. Для них у бурграбія знаходився окремий реєстр. Їх обов'язком було забезпечення рибою двору у випадку приїзду власника Степані [13, арк. 117].

Для будинків в місті відводилися ділянки-пляци, з яких платилося по 18 грошів. Але на окремих пляцах могли проживати й $2-3$, а то й більше непідсусідські родини. Підсумкові свідчення (сумарій) по Степані наводять дані про те, що в місті було 350 пляців, на яких розташовувалося разом 3 передмістями та фільварками 590 помешкань («оsady miasta Stepania z przedmiescziem y folwarkamy 590») та 25 пусток, тобто - всього 615. Очевидно, при «фільварках» мешкали підсусідки, яких було 26 [13, арк. 118]. Для інших, новоосаджених міст Степанської волості такого подрібнення пляців джерела не відзначають. Можна припустити, що як здавна незначне міське поселення Степань при розбудові вимагала розширення міської, оточеної парканами, території, чому могло служити й рішення кн. Я. Острозького про знесення одного з передмість. 
Під фільварками малися, скоріше за все, земельні наділи міщан. Всього в їх користуванні було 79 волок, з яких звільнено від сплати податку та пусток було 32. Найбільш поширеною нормою земельних наділів степанських міщан була одна волока (46 та 13 вільних), але були випадки користування півволочними наділами (двоє міщан) чи спільного користування волокою двома особами чи родинами (два випадки). Володіння двоволочним наділом мало «ранговий» характер - належало чотирьом священикам, монастирю, бурграбію, лісничому - і були звільнені від податків. Такими ж були й одноволочні господарства звіринника, замкових воротного та тивуна, паламаря, міського писаря, війта, старости та шпиталя. Пустих було тільки дві волоки. 3 однієї волоки мали платити по одному злотому, жати по два дні та спільно накосити 12 скирт сіна [13. арк. 117 зв. - 118]. Отже, переважна більшість степанських міщан не мала в своєму розпорядженні землі і була задіяна у ремісничих та торгівельних заняттях.

Повинності степанських міщан не були різноманітними. Вони платили чинш 3 пляців, а хто мав «фільварки» - то й окремо з них, споряджали 10 гайдуків. Лій та мед брався, очевидно тільки від відповідних занять - різників, лісників, бояр тощо. Чинш з Степані був майже втричі меншим за платежі з сіл. Якщо врахувати прибутки та надходження від інших сільських платежів, повинностей, данин, оренд та результатів фільваркового господарювання, то міська складова в загальній прибутковості ще більш суттєво зменшиться. Структура прибутків з міста складалася не тільки з прямих - грошових чи натуральних - платежів, а й з надходжень від млинових оренд. При Степані розташовувалося три млини: під замком, на протилежному боці мосту (по три кола кожен) та на човнах («lodziach») на одне коло. Окремо прибутків з них інвентар не подає, а об’єднує з надходженнями від усіх оренд (млинових та горілчаних) та мит. Ці прибутки суттєво перевищували надходження від податків [13, арк. 118 зв., 154].

Як уже зазначалося, при Степані знаходився звіринець. Він був оточений парканом, а на його території був один критий соломою хлів («шопа»). У звіринці перебували олені (31), сарни (30), лосі (на час створення інвентаря всі вимерли, а було їх 4), дикі свині (12). В звіринці зберігалися роги та шкіри. Троє оленів утекло [13, арк. 119 зв.]. Керував доглядом за звіринцем звіринник.

Під містом знаходився замковий фільварок, в якому мешкав двірник та розташовувалися господарські споруди та помешкання. Фільварок був оточений сосновим острогом-частоколом. Про те, що він був значним господарським осередком можуть свідчити, по-перше, значні розміри висіву та, подруге, кількість сіл, піддані яких в ньому працювали (чотири села: Великий Медськ, Малий Медськ, Корость та Любаша) [13, арк. 119 - 121 зв.]. У фільварковому гумні зберігалися залишки врожаю 1610 - 1613 pp., а з худоби утримувалися тільки велика рогата, а також птиця [13, арк. 119 - 119 зв.].

У складі волості було ще два міських поселення - Бережниця та Деражня, які суттєво поступалися за розмірами центру волості. На відміну від степанських міщан, їх мешканці на 1614 р. чиншів не платили, очевидно, маючи відповідні привілеї як нещодавно осаджені міста. «Міська історія» Деражні почалася у 1605 , а Бережниці - у 1606 р. і пов'язується з рішеннями кн. В.-К. Острозького [12, с. 63]. Але, скоріше за все, це вже було результатами діяльності кн. Я. Острозького. Ці міста, очевидно, мали забезпечувати кілька потреб. Окрім суто міських, пов'язаних зі зростанням сільської складової Степанської волості, вони мали бути проміжковими транспортними осередками на р. Горинь. Так чи інакше, вони були розташовані на кордонах волості та практично рівновіддаленими від центру волості: Деражня південніше, а Бережниця - північніше. Можливо, невдалою була спроба надання міського статусу Кричильську в тому числі й через його близьке розташування до Степані. Створені як міські поселення практично одночасно вони мали відмінності у фортифікації. Помітно краще захищеним поселенням була Деражня. Вона, як і Бережниця, була оточена острогом-парканом, але мала також дві в'їздні башти [13, арк. 131зв., 151].

Не тільки вказана обставина свідчила про інтенсивніший розвиток Деражні як міського поселення. Про це можна говорити і на підставі розмірів цих міст (348 проти 239 будинків), і за розбудовою вуличної мережі (шість та дві). Різними були й розміри ринкових площ, де деражненська в півтора рази переважала бережницьку. Про незавершеність формування Бережниці як міського поселення може свідчити й значна кількість пусток, які могли бути виділеними, але ще не зайнятими пляцами. Їх було дещо менше третини. Більшою (в півтора рази в абсолютних і несуттєво - 4\% а 3\% - у відносних проказниках) була й єврейська громада, при цьому в Деражні проживав один караїм [13, арк. 151]. Деражненська єврейська громада мала «школу», тоді як для Бережниці інвентар згадує тільки «жидівського школьника» [13, арк. 132 зв., 153]. 
Важливим чинником розбудови новоосаджуваних міст було надання міщанам земельних угідь. За цим показником Бережниця також відрізнялася від інших міст волості. У Степані міщани мали в користуванні в середньому городницькі наділи, в Деражні - практично у кожного міщанина було від третини до двох з половиною волок. Опис Бережниці вказівок на наявність землі у міщан не містить [13, арк. 113 - 118 зв., 131 зв. - 134, 151 - 153 зв.].

Свідчення джерел не дають можливості в усій повноті розглянути питання про міське самоврядування у Степанській волості. Але за прізвиськами міщан можна зробити висновок про наявність магдебургського права у Степані та Деражні. У Бережниці єдиною, та й то - дотичною, вказівкою може вважатися згадка бурграбія, що не завжди було пов'язано з міськими органами влади [13, арк. 133 зв.].

При Деражні та Бережниці існували двори. Але при жодному з них не було фільварку. В даних частинах волості останні розташовувалися виключно при селах, а приміські двори виконували резиденційне завдання і призначалися для перебування власника. Про це свідчить вказівка інвентаря стосовно двору в Бережниці - «Dwor xią(żę)czia iego m(czy) przy Berezniczy» [13, арк. 131].

Міста Степанської волості спиралися в своєму розвитку на розгалужену сільську складову. Остання не була однорідною. В ній традиційно виділялися села замкові та посесорські. Їх було практично порівно - 29 та 28. Але серед останніх більшість належала шляхті-слугам, а два сільські поселення (Білобереги та Волька Липленська) - Святомихайлівському монастирю [13, арк. 163]. Ці села, навіть порівняно із посесорськими, були невеликими за розмірами. Замкові села об'єднувались у фільваркові комплекси по 2 (три випадки), 3 (чотири випадки) та 4 (два випадки) села. Найбільші концентрувалися навколо замкового степанського та янковицького (суч. Іваничі) фільварків.

Три села мали урочницький статус і до фільварків не належали, а отже їх піддані до панщинної повинності не залучалися [13, арк. 128, 140, 147]. Серед повинностей селян Степанської волості відсутня підводна (повоз) повинність. Можливо, вона існувала, але здійснювалася в межах самої волості, а далі сплавлялася по річках Горинь та Случ. Особливим податком, незафіксованим у інших випадках, була здача грибів - по 50 з волоки. Можливо, таку ж повинність відбували й інші мешканці на території Полісся.

На 1614 р. у всіх маєтках Степанської волості було проведено поміру, крім одного випадку, який стосувався посесорських держань [13, арк. 160 зв.]. Іноді, але рідко, для замкових сіл не вказуються розміри селянської землі, а згадується тільки категорія селян - тяглі. В таких випадках основою приблизного визначення розмірів селянських наділів $€$ величина повинностей.

Таким чином, можна говорити про те, що інвентар Степанської волості 1614 р. має значний інформаційний потенціал та $є$ унікальним при вивченні поліських латифундій Волині як на рівні урбанізаційних процесів у них, так і становища фільваркового та селянського господарств історичним джерелом. Він, як і інші документи такого роду, подає інформацію з різних сторін соціальної та економічної проблематики, включає загальні описання оборонних, житлових, господарських споруд, переліки населення тощо. Важливим $є$ наявність в степанському інвентарі описань культових споруд (але тільки костелів). Про неповноту інформації може свідчити відсутність вказівок на православні святині, які обов'язково повинні були знаходитися у волинських містах. Він є єдиним збереженим описанням крупного маєткового комплексу східної частини волинського Полісся (не враховуючи частин окремих латифундій частини кн. Олександра Острозького, а для першої половини XVII ст. - повністю поліського маєткового комплексу) і дає можливість на основі його свідчень розглядати розвиток соціально-економічних процесів цього регіону загалом. Частина інвентаря вже була опублікована, але актуальною залишається потреба повного археографічного опрацювання цього важливого джерела з історії Волині.

\section{Список використаних джерел та літератури:}

1. Александрович В. Інвентар Степанського Михайлівського монастиря 1627 року. Украӥнський археографічний щорічник. Київ, 2006. Вип. 10/11. С. 423 - 449.

2. Атаманенко В. Маєткове забезпечення православної церкви Волині в другій половині XVI - першій половині XVII ст. Минуле і сучасне Волині та Полісся: Свято-Троӥиький собор в історії Луцька та Волині. Луцьк, 2005. С. 57- 68.

3. Атаманенко В. Волинські маєтності Острозьких : склад та структура. Наук. записки. Наи. ун-mу «Ocmрозька академі: Iст. науки. Вип. 13. Острог, 2008. С. $266-315$.

4. Атаманенко В. Двори - фільварки Степанської волості (за інвентарним описом 1614 року). Архітектурна спадщина Волині. Наи. ун-т водного госп-ва та природокористування, каф. архітектури. Рівне, 2010. Вип. 2. С. $78-85$. 
5. Атаманенко В. Міста поліських володінь князів Острозьких. Студії з україністики: 3б. наук. праць на пошану дослідника украӥнського козачтва Валерія Цибульського з нагоди 60-річчя від дня народження. Рівне, 2010. C. $191-208$.

6. Атаманенко В. Описи латифундій Волинського Полісся другої половини XVI - першої половини XVII ст. Наук. записки. Нац. ун-ту «Острозька академія»: Iст. науки. Острог, 2011. Вип. 17. С. 29 - 45.

7. Баранович О.І. Залюднення України перед Хмельниччиною: Волинське воєводство. Київ, 1930. 155 с.

8. Берковський В. Інвентарі Подільських та Степанських маєтностей князя Януша Острозького від 1614

1615 pр. Матеріали VII- IX Острозької конференції «Остріг на порозі 900-річчя». 1996-1998 роки. Остріг, 2000. С. $17-18$.

9. Войтович В. Степань моя мила: Дослідження, спогади, документи. Рівне, 2009.

10. Войтович В. Степанський край: Історія та культура. Рівне, 2010.

11. Головний архів давніх актів (Варшава). Архів Коронного Скарбу. №31.

12. Заєць A. Урбанізаційний процес на Волині в XVI - першій половині XVII століття. Львів, 2003.

13. Львівська національна наукова бібліотека ім. В. Стефаника. Ф. «Радзимінські». №.39/I.

14. Собчук В. Степанська волость і її власники (до кінця 60-х років XVIст.) Наук. записки. Наu. ун-ту «Острозька академія»: Iст. науки. Острог, 2011. Вип. 18 . С. $14-41$.

15. Źródła dziejowe. Warszawa, 1889. T.XIX. 485 s. 